\title{
Effect of CNP on composition and structure of lotic biofilms as detected with lectin-specific glycoconjugates
}

\author{
Thomas R. Neu ${ }^{1, *}$, George D. W. Swerhone ${ }^{2}$, Uta Böckelmann ${ }^{3}$, John R. Lawrence ${ }^{2}$ \\ ${ }^{1}$ Department of River Ecology, UFZ Centre for Environmental Research Leipzig-Halle, Brueckstrasse 3A, \\ 39114 Magdeburg, Germany \\ ${ }^{2}$ National Water Research Institute, 11 Innovation Boulevard, Saskatoon, Saskatchewan S7N 3H5, Canada \\ ${ }^{3}$ Department of Microbial Ecology, Technical University, Franklin Strasse 29, 10587 Berlin, Germany
}

\begin{abstract}
Biofilms were cultivated in rotating annular reactors supplied with river water supplemented with carbon, nitrogen, phosphorus or a combined nutrient addition. Confocal laser scanning microscopy and digital image analysis were used in combination with a panel of fluor-conjugated lectin probes to assess the changes in biofilm glycoconjugates with depth, time and in response to the nutrient additions. In addition, nucleic acid staining and autofluorescence were utilised to monitor bacterial and photosynthetic populations respectively. These analyses indicated that in lotic biofilms both quantitative and proportional differences in glycoconjugate composition developed under each nutrient regime. The differences in the biofilms were detected with time and with depth. Comparison of $\mathrm{C}, \mathrm{N}, \mathrm{P}$, and CNP treatments with the control showed differences in the total amount of photosynthetic organisms, bacteria and extracellular polymeric substance (EPS)-specific glycoconjugates. For example, C, N, and CNP nutrient additions resulted in a minimal increase of $50 \%$ lectin-specific EPS glycoconjugates. Accumulation of different glycoconjugates over time in the different biofilms showed a similar pattern in the single nutrient treatments, with a maximum accumulation at $3 \mathrm{wk}$, followed by sloughing in Week 5 and regrowth in Week 7. In contrast, both the control and the combined CNP treatment showed a continuous increase and a plateau phase for the glycoconjugates as a whole. Both visualisation and quantification indicated that under each treatment the distribution of 4 specific glycoconjugates (Arachis hypogaea, Canavalia ensiformis, Glycine max, Ulex europaeus) varied with depth and, in addition, changed over time. Further, the glycoconjugate make-up of the single nutrient additions were similar to each other, as was the make-up of the control and combined nutrient treatment. Application of fluorescence in situ hybridisation analysis indicated that significant changes occurred in the beta-proteobacteria community composition as a consequence of nutrient addition. The results demonstrate the effect of nutrient regime on the cellular composition and glycoconjugate chemistry of lotic biofilms.
\end{abstract}

KEY WORDS: Biofilms · Lectins - Extracellular polymeric substances · EPS · Glycoconjugates · Nutrients $\cdot$ Fluorescence $\cdot$ Confocal laser scanning microscopy $\cdot$ CLSM

\section{INTRODUCTION}

Extracellular polymeric substances (EPS) act as multifunctional elements in microbial communities (Wolfaardt et al. 1999). Within interfacial microbial communities they play many roles in the interaction with the environment and between biofilm organisms.
The capacity of EPS compounds to bind a variety of molecules is based on the presence of a wide range of reactive moieties within their structure (Flemming et al. 1996). These may include ionic groups and hydrophobic residues. The presence of ionic groups such as carboxyl, phosphoyl and sulfonyl potentially allow the complexation of cations including metals 
(Geesey et al. 1989). Some amino sugars and proteins are also cationic and may provide sites for binding of anionic compounds (Decho 1990). Hydrophobic binding capacity has also been observed in biofilms, resulting in sorption of hydrocarbons and other non-polar contaminants (Wolfaardt et al. 1998) as well as dissolved organic matter (Freeman \& Lock 1995). Nevertheless, the identity and function of EPS compounds within complex environmental microbial systems is poorly understood. Traditional approaches require the isolation and purification of polymers with subsequent chemical characterisation (Nielsen \& Jahn 1999). For environmental samples, this approach may be very difficult if not impossible, as microbial EPS comprise several different polymer classes which are again composed of numerous polymers with very different chemical characteristics (Wingender et al. 1999). In addition, the spatial information of glycoconjugate arrangement is lost when EPS is extracted from the biofilm. This may be important for the function of specific EPS within biofilms.

Recently, we have developed in situ techniques to investigate the structure of complex interfacial microbial biofilms. These include the detection and quantification of cellular and polymeric compounds in biofilms (Neu \& Lawrence 1997), the development of biofilm microcosms for replicated biofilm studies (Lawrence et al. 2000), and in situ visualisation and localisation of contaminants in biofilms (Lawrence et al. 2001). Furthermore, techniques have been developed to facilitate the quantitative characterisation of EPS in situ by using fluor-conjugated lectins (Wolfaardt et al. 1998, Neu 2000, Neu et al. 2001). It is also possible to apply multi-channel confocal laser scanning microscopy (CLSM) to assess different biofilm parameters such as bacterial, cyanobacterial and algal biomass in combination with lectin-specific EPS biomass (Lawrence et al. 1998). The combination of lectin-binding analysis (LBA) with fluorescence in situ hybridisation (FISH) has also been shown (Böckelmann et al. 2002).

Nutrients are a major concern in rivers because of their introduction in agricultural runoff, municipal sewage, and industrial effluents such as pulp mills (Jickells 1998). Significant changes in microbial community structure have been observed in response to nutrients; however, limited data exist on their impact on the chemical nature of EPS in river biofilm systems. Mohamed et al. (1998) demonstrated that pulp mill effluents, and in particular phosphorus additions, significantly altered the community structure of river biofilms as well as the EPS quantities produced. Other studies have also indicated that nutrients have an effect on polymer production (Bonet et al. 1993). The EPS produced by bacteria or algae may be strainspecific, influenced by growth rate and metabolic stress (Uhlinger \& White 1983). Regardless of their origin, the EPS may accumulate ionic and hydrophobic compounds and consequently will have a significant impact on the short-term retention and potential fate of contaminants in the environment.

By employing a range of CLSM-based imaging techniques in combination with digital image analysis, we investigated the impact of nutrients on the form, arrangement and composition of river biofilms and their lectin-specific EPS compounds. Biofilms were grown using nutrient-limited waters from the South Saskatchewan River, Canada, with additions of carbon, nitrogen, phosphorus and a combination of these nutrients to reflect those that would be typically introduced by pulp mill effluent or sewage effluent additions. An understanding of these changes in the EPS is important because it may influence the sorption and fate of contaminants, the nutritive value of the biofilm for grazers and play a role in water quality; therefore, these polymeric biofilm components are the focus of this study.

\section{MATERIALS AND METHODS}

Biofilm culture and treatments. Lotic biofilms were developed as previously described in detail (Lawrence et al. 2000). Briefly, rotating annular reactors containing removable polycarbonate slides which could be used directly for microscopic examination of biofilms were set up for biofilm development. The reactors were run with continuous illumination $\left(2.1 \mu \mathrm{E} \mathrm{s}^{-1} \mathrm{~m}^{-2}\right)$ in a recirculating mode with weekly changes of the recirculating water and additions of the nutrient treatments. For each of the 5 treatments, 3 replicate reactors were operated in parallel. The control reactors were inoculated and fed with river water only. Nutrients were added to the other reactors. Carbon was

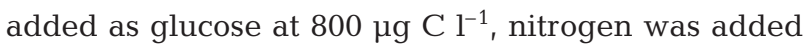
as ammonium chloride at $80 \mu \mathrm{M} \mathrm{N}^{-1}$, phosphorus was added as potassium phosphate at $5 \mu \mathrm{M} \mathrm{P}^{-1}$ and carbon, nitrogen and phosphorus (CNP) were added at the same concentrations as above. The nutrient levels are based on those used by Mohamed et al. (1998), which were calculated to be capable of producing $2 \times$ $10^{8}$ cells $\mathrm{ml}^{-1}$ and were relevant to typical nutrient levels resulting from pulp mill effluent additions. Nutrient analyses (Table 1) were carried out to provide information on in situ nutrient levels and nutrient consumption in the reactors using standard methods (Environment Canada 1992). Sampling and analyses of the biofilms occurred on a weekly basis (Days 7, 14, 21, 28, 35, 42, 49) during a 7 wk experimental period.

Fluorescent staining and lectin-binding analysis. Bacteria in the biofilms were stained with the nucleic 
Table 1. Water-chemistry data $\left(\mathrm{mg} \mathrm{l}^{-1}\right)$ for South Saskatchewan River water in control and nutrient-amended reactors, showing initial/7 d values. TP: total phosphorus

\begin{tabular}{|lcccccc|}
\hline Treatment & TP & Ortho-P & DOC & $\mathrm{NH}_{4}-\mathrm{N}$ & $\mathrm{NO}_{3}+\mathrm{NO}_{2}-\mathrm{N}$ & $\mathrm{pH}$ \\
\hline Control & $0.02 / 0.002$ & $0.003 / 0.002$ & $3.0 / 3.3$ & $0.012 / 0.006$ & $0.188 / 0.010$ & $8.3 / 8.4$ \\
$\mathrm{C}$ & $0.016 / 0.002$ & $0.002 / 0.002$ & $3.8 / 3.2$ & $0.012 / 0.005$ & $0.186 / 0.010$ & $8.2 / 8.2$ \\
$\mathrm{~N}$ & $0.016 / 0.003$ & $0.002 / 0.002$ & $3.2 / 3.2$ & $1.75 / 0.27$ & $0.186 / 0.37$ & $8.2 / 7.8$ \\
$\mathrm{P}$ & $0.16 / 0.01$ & $0.14 / 0.008$ & $3.1 / 3.1$ & $0.012 / 0.005$ & $0.188 / 0.010$ & $8.2 / 8.5$ \\
$\mathrm{CNP}$ & $0.16 / 0.01$ & $0.12 / 0.002$ & $3.3 / 3.5$ & $0.99 / 0.007$ & $0.188 / 0.011$ & $8.3 / 8.4$ \\
\hline
\end{tabular}

placed at the edges of the slides. Subsequently, the slides were transferred to $50 \mathrm{ml}$ pre-warmed washing buffer (20 mM Tris/ $\mathrm{HCl}, 0.01 \% \mathrm{SDS}, \mathrm{NaCl}$ ) and incubated at $48^{\circ} \mathrm{C}$ for $20 \mathrm{~min}$. For microscopic analysis, the slides were carefully rinsed with distilled water, air-dried and mounted in anti-fading glycerol medium (Citifluor AF2). All hybridisation and washing steps were performed in the dark.

acid-specific SYTO 9, one component of the Baclight staining kit or SYTO 63 (Molecular Probes). Photosynthetic biomass was estimated using autofluorescence signals in the far red, as described by Lawrence et al. (1998). Lectins with fluorescein isothiocyanate (FITC) labelling were purchased (Sigma). The lectins used in this study are listed in Table 2. For staining, the lectins were dissolved at $100 \mu \mathrm{g} \mathrm{ml}^{-1}$ in filter-sterilised $(0.2 \mu \mathrm{m})$ river water. The slide pieces $\left(1 \mathrm{~cm}^{2}\right)$ that carried the biofilm were directly stained with $100 \mu$ of the lectin solution. The samples were then incubated for 20 min at room temperature in a humid chamber. After staining, the slide pieces were carefully rinsed with filter-sterilised river water 4 times to remove unbound lectins. The procedure of lectin-binding analysis has been described in detail elsewhere (Neu \& Lawrence 1999a,b).

Fluorescent in situ hybridisation (FISH). Fixation was done following the protocol of Manz et al. (1999). Beta42a proteobacterial oligonucleotide probe (Interactiva) was stored in TE buffer (10 mM Tris, 1 mM EDTA, $\mathrm{pH} 7.5)$ at $-20^{\circ} \mathrm{C}$. Working solutions were adjusted to $50 \mathrm{ng}$ DNA ml${ }^{-1}$. Pre-warmed hybridisation buffer $(0.9 \mathrm{M}$ $\mathrm{NaCl}, 20$ mM Tris/ $\mathrm{HCl}$ [pH 7.2], $0.01 \%$ SDS, formamide $35 \%$ ) was mixed with fluorescently labelled oligonucleotide ( $1 \mathrm{ng} \mathrm{ml}^{-1}$ hybridisation buffer) and applied to the fixed biofilm material. The slides were placed in humid chambers and incubated for $90 \mathrm{~min}$ at $46^{\circ} \mathrm{C}$. Thereafter, hybridisation buffer was drawn off with tissue

Table 2. Lectins used in this study. EPS: extracellular polymeric substances; FITC: fluorescein isothiocyanate; TRITC: tetramethylrhodamine isothiocyanate

\begin{tabular}{|lll|}
\hline Lectin & Conjugate & $\begin{array}{l}\text { Sugar residue detected } \\
\text { (according to data sheet) }\end{array}$ \\
\hline Arachis hypogaea & FITC & $\begin{array}{l}\text { Galactose, N-acetyl } \\
\text { galactosamine } \\
\text { Mannose, glucose }\end{array}$ \\
$\begin{array}{l}\text { Canavalia ensiformis } \\
\text { Glycine max }\end{array}$ & FITC & $\begin{array}{l}\text { N-acetyl galactosamine } \\
\text { Ulex europaeus }\end{array}$ \\
$\begin{array}{l}\text { Triticum vulgaris } \\
\text { (total EPS) }\end{array}$ & FITC & Fucose \\
\hline
\end{tabular}

Confocal laser scanning microscopy and digital image analysis. Examination of all samples was carried out using an MRC 1024 (BioRad) attached to a Microphot SA microscope (Nikon). For observation, the following water-immersible lenses were available: $63 \times 0.9$ numerical aperture (NA) (Zeiss) and $40 \times$ 0.55 NA (Nikon). Emission signals were recorded in the green channel (excitation $488 \mathrm{~nm}$, emission $522 / 32 \mathrm{~nm}$ ), the red channel (excitation $568 \mathrm{~nm}$, emission 605/32 nm) and the far-red channel (excitation $647 \mathrm{~nm}$, emission 680/32 nm). Files were printed from Photoshop Version 5.5 (Adobe) using a colour printer.

Image analyses were performed using Scion Image Version 1.62 for Mac OS (available at: http:// scioncorp.com) with a macro written for semi-automated quantification. Image analyses were used to define the area of bacterial and algal cells and determine the area and volume of these biofilm components. Image analysis was also used to define the area of the biofilm binding a specific lectin. For this purpose the threshold was set manually by the operator. In addition, the average grey value of the defined area was examined. These 2 parameters were used according to Eq. (1) to quantify the area binding a specific lectin (Neu et al. 2001).

$$
\% \mathrm{ICBA}=\frac{\mathrm{TA} \times \mathrm{AGV} \times 100}{255 \times 393216}
$$

where \%ICBA = intensity-corrected binding area, $\mathrm{TA}=$ thresholded area of lectin binding, AGV = average grey value within thresholded area, $255=$ grey value of saturated pixels, and $393216=$ number of pixels in a full image $(768 \times 512)$.

Statistical analyses. All experiments were carried out in triplicate (3 reactors in parallel), with 1 subsample per replicate (1 from each reactor) and 5 analyses per slide piece ( 5 fields of view), resulting in $n=15$. Images were collected from the biofilm attachment surface to the biofilm bulk phase interface as dictated by biofilm thickness. For FISH analyses, 20 microscope fields were examined for each replicate reactor. The resultant data were tabulated, collated and subjected to analyses of variance and Pearson correlation analyses using the commercial statistical package MiniTab. 


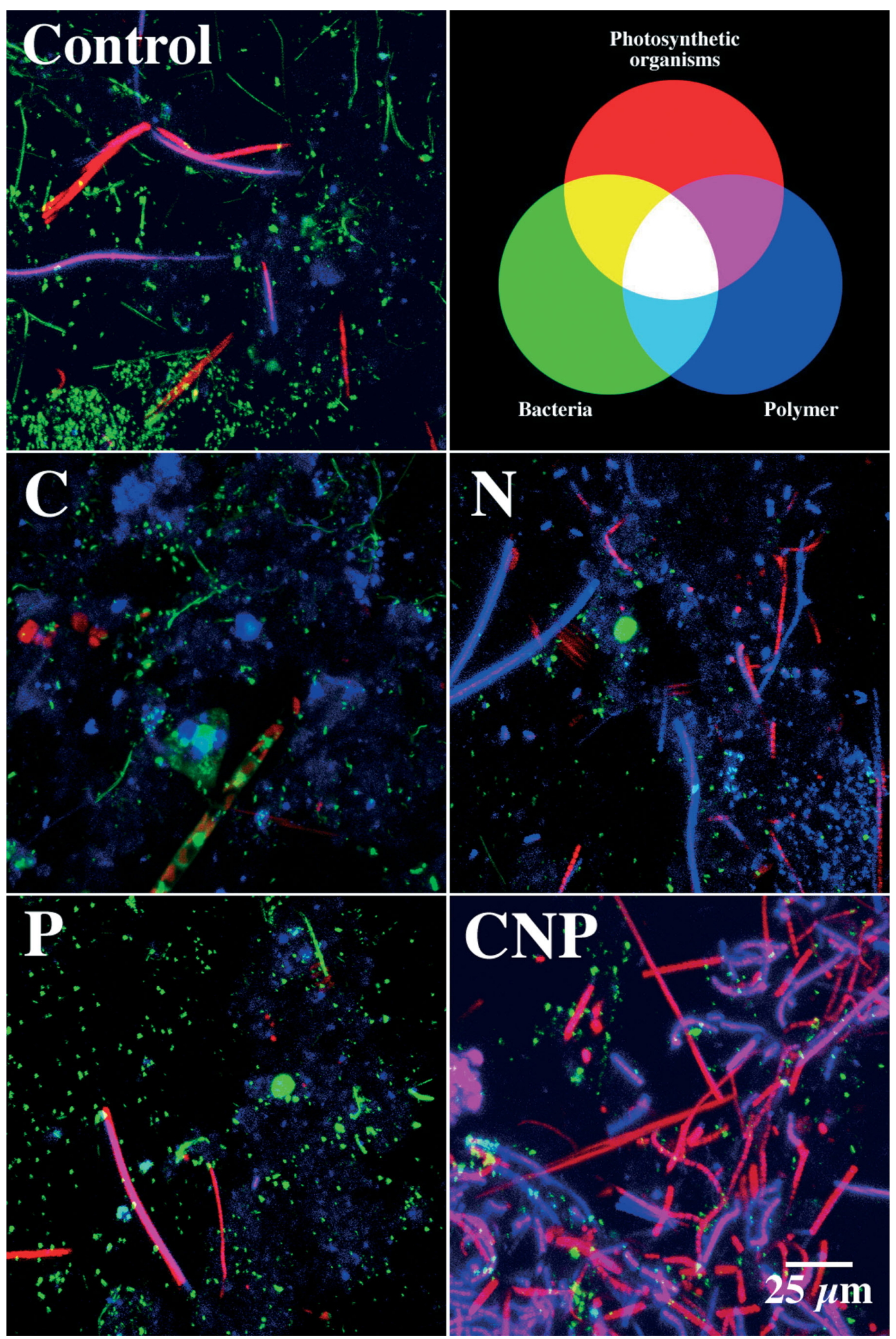

Fig. 1. Three-channel maximum intensity projections of confocal laser scanning micrographs (CLSM) showing structure and composition of control and nutrient-treated lotic biofilms at Week 7. Sections taken $5 \mu \mathrm{m}$ apart. Control: 29 optical sections; $\mathrm{C}$ (carbon): 24; N (nitrogen): 21; P (phosphorus): 17; CNP (carbon, nitrogen and phosphorus): 24. Colour wheels indicate assignment of colours in the images - green: bacteria; red: algae; blue: EPS glycoconjugates 


\section{RESULTS AND DISCUSSION}

\section{Effect of nutrients on biofilm development}

We used lotic biofilms to examine the effect of nutrient additions on biofilm development and the production of specific glycoconjugates. The architecture, thickness and community composition were markedly influenced by all of the nutrient amendments (Figs. 1 \& 2 , Table 3 ). The addition of combined CNP resulted in a significant increase in photosynthetic biomass and reduction in bacterial biomass relative to control biofilms $(p<0.05)$. Application of single nutrients also influenced biofilm development, but to a lesser degree, with the addition of nitrogen resulting in the greatest depression of bacterial numbers. Further, the single nutrients reduced photosynthetic biomass. Biofilm thickness was influenced by nutrient additions; P and CNP treatments were significantly thicker during the first $3 \mathrm{wk}$, and these treatments tended to remain the thickest, although by Week 7 only the CNP treatment was significantly thicker than the others (Table 3). Nutrient treatments resulted in a $\geq 50 \%$ increase in lectin-specific EPS glycoconjugates in $\mathrm{C}, \mathrm{N}$, and CNP treatments by Week 7 (Fig. 2). The general pattern of river biofilm development paralleled that previously described in detail by Lawrence et al. (2001), Manz et al. (1999), and Neu \& Lawrence (1997).

The time course of glycoconjugate accumulation (Fig. 3) indicates that the biofilm development rates for single nutrient treatments $(C, N, P)$ and between the control and CNP treatment were similar over $7 \mathrm{wk}$. Lectin-specific EPS glycoconjugates in the control and CNP treatment increased over a period of 1 to $3 \mathrm{wk}$, followed by a plateau phase up to Week 7 . In contrast, single nutrient additions reached a maximum at Week 3 followed by a sloughing event at Week 5 and subsequent recovery by the end of the experiment (Fig. 3).

Sloughing events may play a critical role in the development of biofilm architecture and community structure. However, questions regarding their effect on EPS composition and distribution in response to envi-

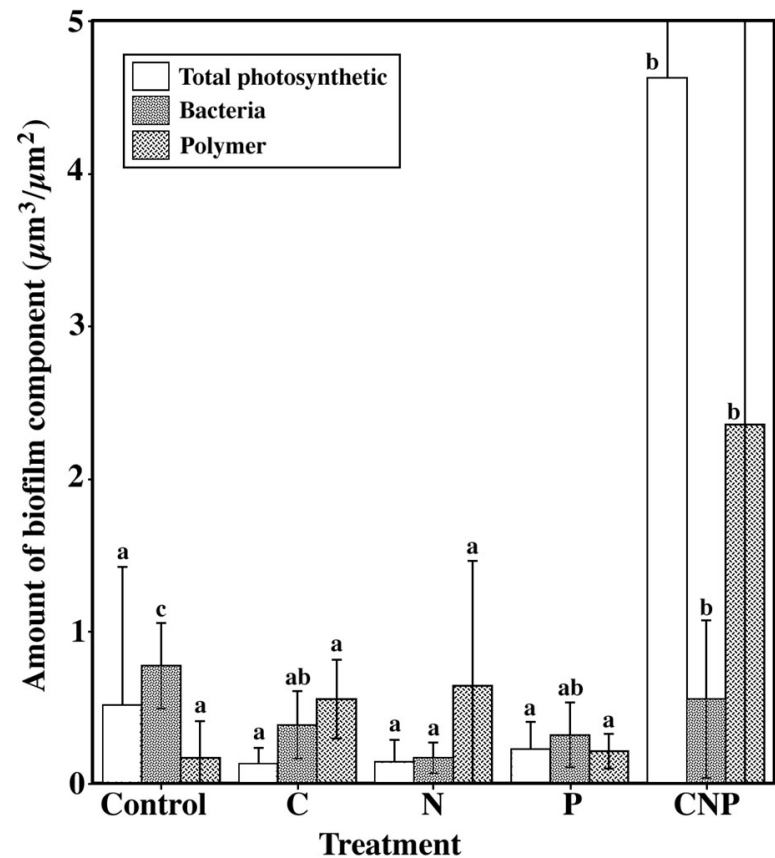

Fig. 2. Biofilm communities at Week 7, showing photosynthetic organisms (algae and cyanobacteria), bacteria and 'total' lectin-specific EPS (Triticum vulgaris) composition. Data are actual values $( \pm \mathrm{SD})$ used to calculate proportions

ronmental variation have not been addressed. We suggest that the sloughing events observed in the biofilms may account for the further changes in the proportional composition of lectin-specific EPS detected in Week 7 (Fig. 4). In addition, these events account for the apparent changes in the vertical distribution graphs for EPS quantity and composition (Fig. 5). Fig. 5 shows a loss of biofilm material and a change of architecture in this interval, which is again consistent with a sloughing event.

\section{Lectin binding and glycoconjugate diversity}

In the present study of South Saskatchewan River biofilms, FITC-conjugated lectins were applied in preference to other fluor-conjugated forms, because of the

Table 3. Thickness $(\mu \mathrm{m})$ of biofilm over time (wk). Values in each column with same letter are not significantly different at $p=0.05$ ( 3 reactors, 1 slide each, 5 fields of view, $\mathrm{n}=15$ )

\begin{tabular}{|c|c|c|c|c|c|c|c|}
\hline \multirow{2}{*}{ Treatment } & & & & \multirow{2}{*}{$\begin{array}{l}\text { Time (wk) } \\
4\end{array}$} & \multirow[b]{2}{*}{5} & \multirow[b]{2}{*}{6} & \multirow[b]{2}{*}{7} \\
\hline & 1 & 2 & 3 & & & & \\
\hline Control & $17 \pm 5 a$ & $43 \pm 14 a$ & $70 \pm 25 b$ & $98 \pm 29 a$ & $137 \pm 53 \mathrm{bc}$ & $111 \pm 33 a b$ & $155 \pm 64 \mathrm{bc}$ \\
\hline $\mathrm{C}$ & $18 \pm 6 a$ & $38 \pm 14 a$ & $53 \pm 20 a$ & $101 \pm 49 a$ & $120 \pm 51 \mathrm{ab}$ & $140 \pm 60 \mathrm{bc}$ & $135 \pm 49 \mathrm{abc}$ \\
\hline $\mathrm{N}$ & $22 \pm 6 a$ & $45 \pm 20 \mathrm{a}$ & $63 \pm 24 a b$ & $118 \pm 37 a b$ & $96 \pm 33 a$ & $87 \pm 36 a$ & $97 \pm 34 a$ \\
\hline $\mathrm{P}$ & $22 \pm 7 a$ & $81 \pm 37 b$ & $98 \pm 39 c$ & $138 \pm 43 b$ & $136 \pm 39 \mathrm{bc}$ & $145 \pm 42 \mathrm{C}$ & $129 \pm 52 \mathrm{ab}$ \\
\hline CNP & $41 \pm 16 b$ & $82 \pm 26 b$ & $104 \pm 47 \mathrm{c}$ & $144 \pm 50 b$ & $165 \pm 42 c$ & $155 \pm 30 \mathrm{c}$ & $169 \pm 62 c$ \\
\hline
\end{tabular}




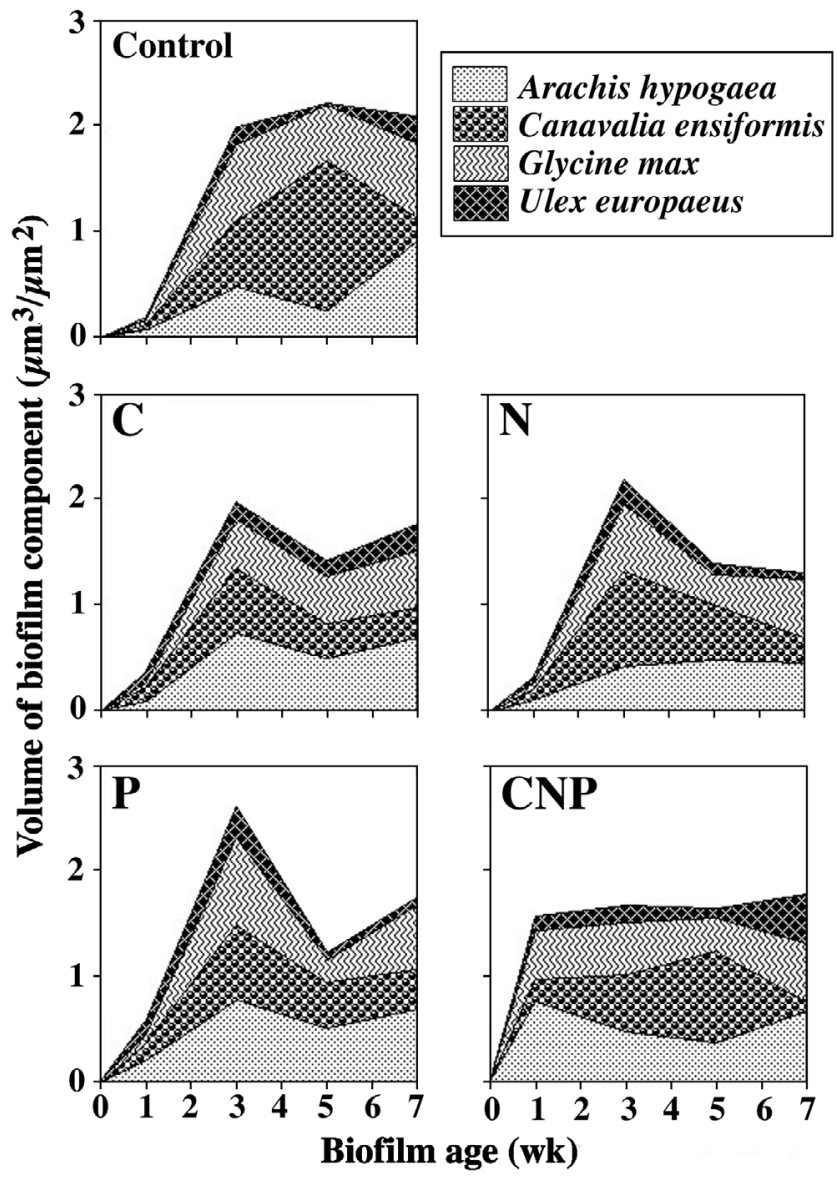

Fig. 3. Time-course of binding volume of the 4 different lectinspecific EPS glycoconjugates in control and nutrient-treated biofilm communities minor impact of this fluor on binding specificity (Neu et al. 2001). The fluor-conjugated lectins Arachis hypogaea-FITC, Canavalia ensiformis-FITC, Glycine maxFITC, and Ulex europeaus-FITC also provided a range of binding affinities and glycoconjugate recognition, and were found to allow visualisation of discrete regions within the biofilms (Table 2). Although Table 2 does not address the high diversity of glycoconjugates present in natural biofilms, it provides an index of the nature of lectin-specific EPS in biofilms. It may be important to note that the high diversity of glycoconjugates detected in biofilms is at odds with the growing application of alginate as a model biofilm polymer. Alginate production is important because of its medical significance and biochemical properties (Sabra et al. 2001). However, if bacterial biodiversity is related to potential EPS diversity, it becomes clear that alginate is only one of numerous compounds which may be found in the environment. The current study and those of Neu et al. (2001) and Staudt et al. (2003) using river biofilms clearly confirm the extensive diversity of glycoconjugates present in these natural habitats, a factor that must ultimately be addressed to understand the roles of EPS in natural microbial systems.

\section{Spatial variation of glycoconjugates}

Few studies have addressed the spatial variation of glycoconjugates in biofilms or aggregates (Böckelmann et al. 2000, Neu 2000). In the present study, we were able to demonstrate the presence of considerable
1 wk
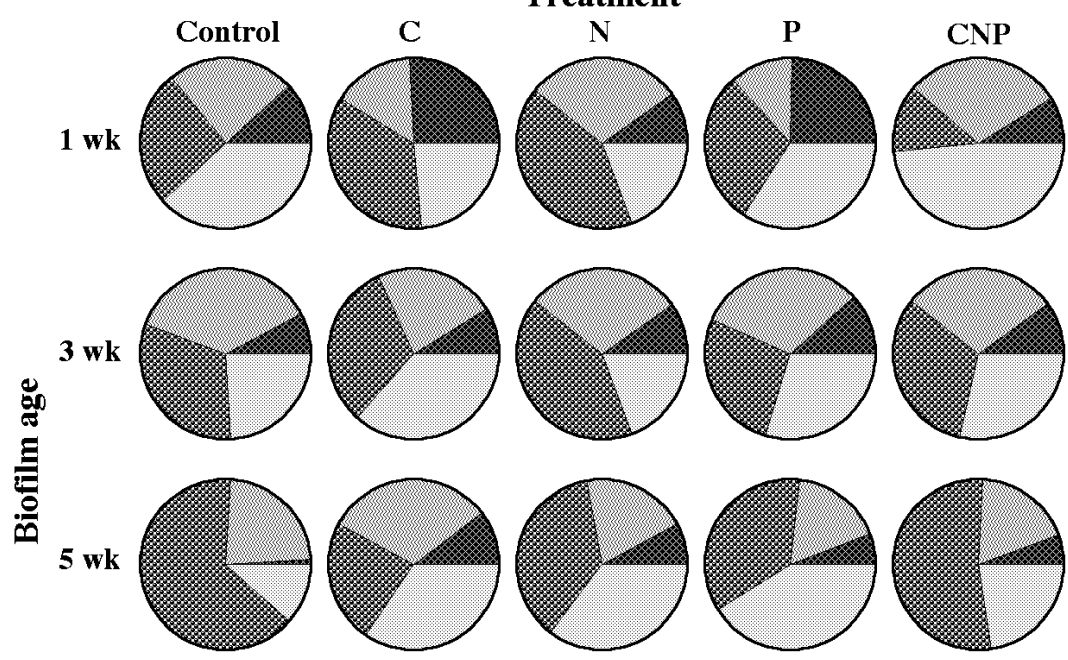

7 wk
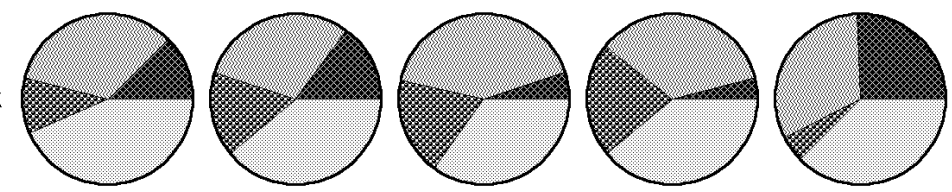

Fig. 4. Proportional contribution of glycoconjugates to lectin-specific EPS as a function of time and treatment 


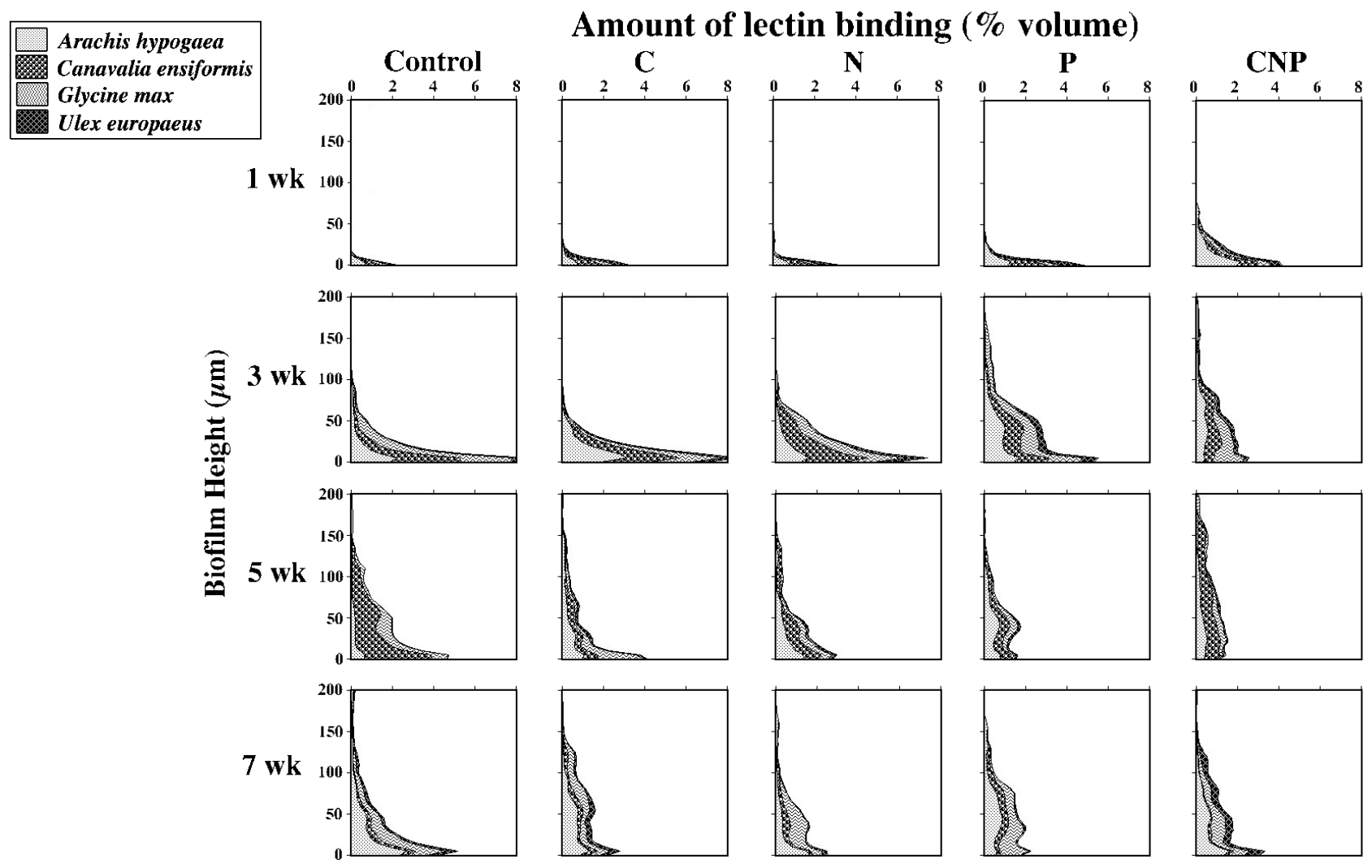

Fig. 5. Results of digital image analysis showing vertical profiles of 4 different glycoconjugates

$\mathrm{XY}$ and XZ spatial and compositional variation of lectin binding in the biofilms. The visual differentiation of 4 specific glycoconjugates is illustrated in Fig. 6 with a series of XY CLSM images. These show clearly the differential binding of the various lectins, depending on the nutrients added. The addition of single nutrients $\mathrm{C}, \mathrm{N}$ or $\mathrm{P}$ resulted in very similar patterns of glycoconjugates. The control and the CNP additions also resulted in similar signals (Fig. 6). Again it is apparent in these images that the control and the CNP additions both followed a different pattern than the single nutrient additions, but a similar pattern compared to each other.

Fig. 5 shows vertical profiles of each of the biofilms with time, illustrating the impact of the treatments on the vertical development and architecture of each biofilm. Comparisons of the vertical distribution of algae, bacteria and total lectin-specific EPS glycoconjugates through Pearson correlation analyses indicated that these biological variables were tightly intercorrelated and correlated $(\mathrm{p}<0.05)$ with lectin-binding patterns (Table 4). In general, these distributions reflected the distribution of total biomass and the biofilm architecture; however, Arachis hypogaea binding sites were often more concentrated in the basal region of the biofilms, whereas Glycine max was more prominent in surface regions. There were also changes in the strength of the linear relationship with time, for example in treatments involving phosphorus there was a trend for a weakening relationship between photosynthetic biomass or bacterial biomass and lectin binding over time (Table 4). Changes may be of significance in the fate of contaminants in microbial biofilms, e.g. as noted for Diclofop by Wolfaardt et al. (1998).

\section{Effects of nutrients on temporal variation of glycoconjugates}

Fig. 4 shows the proportion of glycoconjugates as a function of time and treatment. In general, there are similarities in the proportional distribution of glycoconjugates in the single nutrients as well as between the control and CNP treatment. The proportion of glycoconjugates in the control and CNP treatment is similar if Weeks 1, 3, 5 and 7 are compared. In detail, Canavalia ensiformis increased in both systems from Weeks 1 to 5 and decreased in Week 7, whereas Ulex europaeus and Arachis gypogaea glycoconjugates decreased from Weeks 1 to 5 and increased in Week 7. The proportion of glycoconjugates in single $\mathrm{C}, \mathrm{N}$ and $\mathrm{P}$ treatments was variable. For example, C. ensiformis 


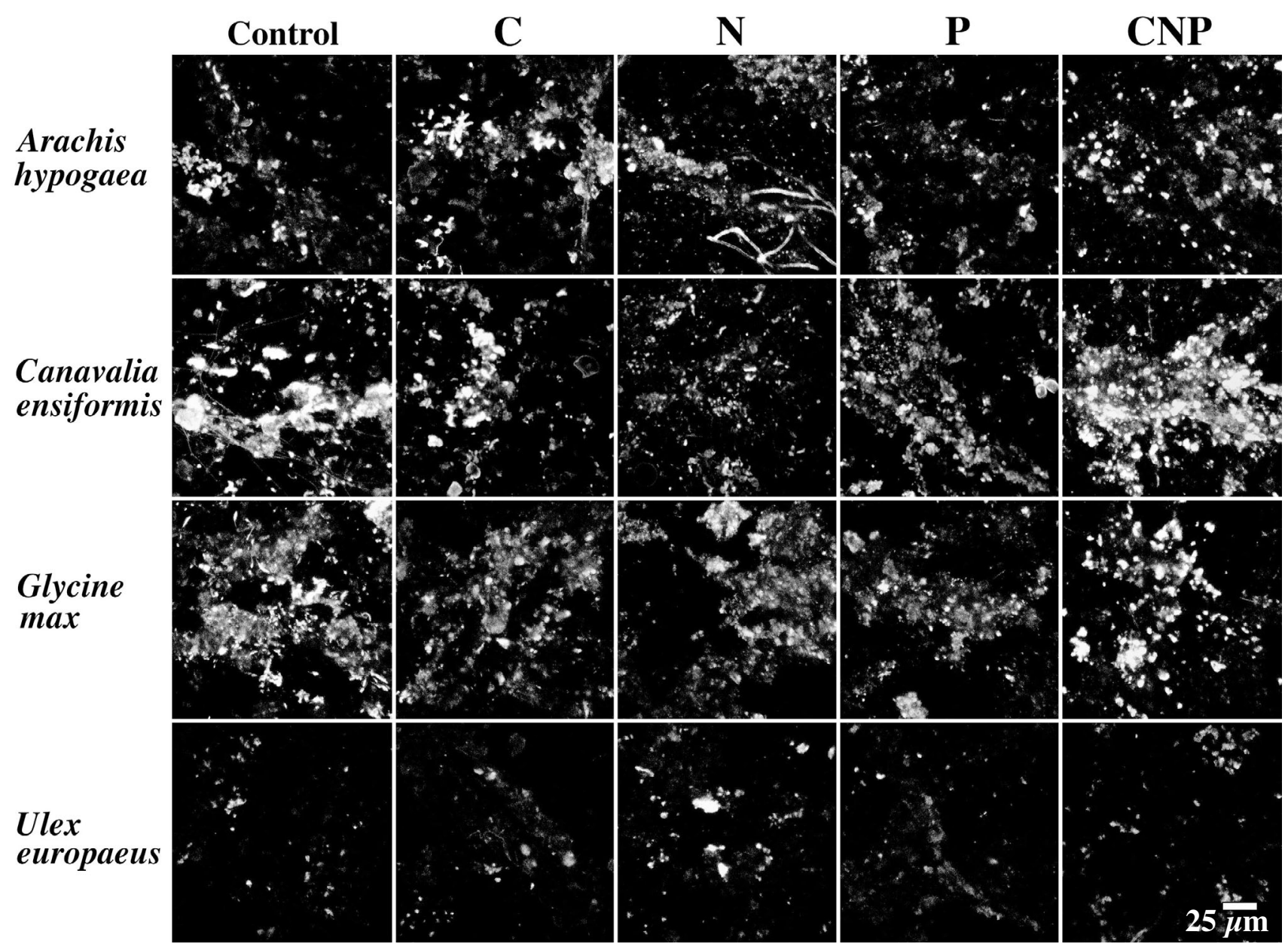

Fig. 6. Series of XY single-channel CLSM images illustrating differential binding of various fluor-conjugated lectins in control and nutrient-treated biofilms

decreased from Weeks 1 to 7, also Ulex europaeus, in general, declined-with the exception of an increase in the carbon treatment in Week 7. Pearson correlation analyses revealed some significant relationship between the pattern of lectin binding and the quantities of algae, bacteria and total EPS at Week 7. In the C treatment, bacteria and algal biomass were significantly positively correlated (1.00, p $\leq 0.05)$ whereas in the $\mathrm{N}$ treatment they were significantly negatively correlated $(-1.00, \mathrm{p} \leq 0.05)$. In the $\mathrm{P}$ treatment, total EPS was correlated with bacteria $(0.98, \mathrm{p} \leq 0.05)$; in contrast, in the CNP treatment, total EPS was correlated with algae $(0.98, \mathrm{p} \leq 0.05)$. In both the $\mathrm{P}$ and CNP treatments, total EPS and $U$. europaeus lectin binding were positively correlated $(0.98, \mathrm{p} \leq 0.05)$. In the control biofilm, $U$. europaeus was also correlated with $A$. hypogaea $(0.97, \mathrm{p} \leq 0.05)$, and $A$. hypogaea was correlated with algal biomass $(0.93, \mathrm{p} \leq 0.05)$. A. hypogaea lectin also had a strong positive relationship with algal biomass and a negative relationship with bacterial biomass $(0.99, p \leq 0.05)$ in the nitrogen treatment. These results suggest that changes in the abundance and nature of the EPS are at least in part explained by the changing relationship between bacteria and algae in these biofilms. Furthermore, these changes may represent changes in the nutritional value of the biofilm as food supply, or its capacity to sorb both nutrients and contaminants. This may be speculative at this point, but nonetheless relevant.

In addition to the analyses of trends in the lectinbinding data, a statistical evaluation of the quantitative data was carried out using analysis of variance (Table 5). This analysis, over the $7 \mathrm{wk}$ of study, indicated that there were no significant detectable quantitative changes $(p=0.05)$ in the treated versus control biofilms in terms of Glycine max binding patterns; in contrast, Arachis hypogaea showed statistically significant increases in binding in C-, P- and CNP-treated biofilms in Weeks 1 and 3. The results of analyses using Canavalia ensiformis indicated detectable increases and decreases in the P and CNP treatments for Weeks 1 and 7, and for all treatments in Week 5. 
Table 4. Correlation analysis of vertical distribution of algae, bacteria, EPS and lectin binding (S: strong; M: moderate, W: weak) over 7 wk study period (1-7)

\begin{tabular}{|c|c|c|c|c|c|c|c|c|c|c|c|c|c|c|c|c|c|c|c|c|c|c|c|c|}
\hline \multirow[t]{2}{*}{ Treatment } & \multicolumn{4}{|c|}{$\begin{array}{l}\text { Total photosyn- } \\
\text { thetic organisms }\end{array}$} & \multicolumn{4}{|c|}{$\begin{array}{c}\text { Total } \\
\text { bacteria }\end{array}$} & \multicolumn{4}{|c|}{$\begin{array}{c}\text { Total polymer } \\
\text { (Triticum vulgaris) }\end{array}$} & \multicolumn{4}{|c|}{$\begin{array}{c}\text { Arachis } \\
\text { hypogaea }\end{array}$} & \multicolumn{4}{|c|}{$\begin{array}{l}\text { Canavalia } \\
\text { ensiformis }\end{array}$} & \multicolumn{4}{|c|}{$\begin{array}{l}\text { Glycine } \\
\max \end{array}$} \\
\hline & 1 & 3 & 5 & 7 & 1 & 3 & 5 & 7 & 1 & 3 & 5 & 7 & 1 & 3 & 5 & 7 & 1 & 3 & 5 & 7 & 1 & 3 & 5 & 7 \\
\hline \multicolumn{25}{|l|}{ Control } \\
\hline Arachis hypogaea & $\mathrm{S}$ & $\mathrm{S}$ & $\mathrm{M}$ & W & $\mathrm{S}$ & $\mathrm{S}$ & W & $\mathrm{M}$ & $\mathrm{S}$ & $\mathrm{S}$ & W & $\mathrm{M}$ & & & & & & & & & & & & \\
\hline Canavalia ensiformis & $\mathrm{M}$ & $\mathrm{S}$ & $\mathrm{S}$ & $\mathrm{W}$ & $\mathrm{S}$ & $\mathrm{S}$ & M & $\mathrm{M}$ & $\mathrm{S}$ & $\mathrm{S}$ & M & $\mathrm{M}$ & $\mathrm{S}$ & $\mathrm{S}$ & $\mathrm{S}$ & $\mathrm{S}$ & & & & & & & & \\
\hline Glycine max & $\mathrm{S}$ & $\mathrm{S}$ & $\mathrm{M}$ & W & $\mathrm{S}$ & $\mathrm{S}$ & $\mathrm{M}$ & $\mathrm{M}$ & $\mathrm{S}$ & $\mathrm{S}$ & $\mathrm{M}$ & $\mathrm{M}$ & $\mathrm{S}$ & $\mathrm{S}$ & $\mathrm{S}$ & $\mathrm{S}$ & $\mathrm{S}$ & $\mathrm{S}$ & $\mathrm{S}$ & $\mathrm{S}$ & & & & \\
\hline Ulex europaeus & $\mathrm{M}$ & $\mathrm{S}$ & W & $\mathrm{W}$ & $\mathrm{S}$ & $\mathrm{S}$ & W & $\mathrm{M}$ & $\mathrm{S}$ & $\mathrm{S}$ & W & $\mathrm{M}$ & $\mathrm{S}$ & $\mathrm{S}$ & $\mathrm{M}$ & $\mathrm{S}$ & $\mathrm{S}$ & $\mathrm{S}$ & M & $\mathrm{S}$ & $\mathrm{S}$ & $\mathrm{S}$ & $\mathrm{S}$ & $\mathrm{S}$ \\
\hline \multicolumn{25}{|l|}{$\mathbf{C}$} \\
\hline Arachis hypogaea & $\mathrm{S}$ & $\mathrm{S}$ & $\mathrm{M}$ & $\mathrm{S}$ & $\mathrm{S}$ & $\mathrm{S}$ & $\mathrm{M}$ & $\mathrm{M}$ & $\mathrm{S}$ & $\mathrm{S}$ & $\mathrm{M}$ & $\mathrm{M}$ & & & & & & & & & & & & \\
\hline Canavalia ensiformis & $\mathrm{S}$ & $\mathrm{S}$ & $\mathrm{M}$ & $\mathrm{M}$ & $\mathrm{S}$ & $\mathrm{S}$ & $\mathrm{S}$ & $\mathrm{M}$ & $\mathrm{S}$ & $\mathrm{S}$ & $\mathrm{S}$ & M & $\mathrm{S}$ & $\mathrm{S}$ & $\mathrm{S}$ & $\mathrm{M}$ & & & & & & & & \\
\hline Glycine $\max$ & $\mathrm{S}$ & $\mathrm{S}$ & $\mathrm{W}$ & $\mathrm{M}$ & $\mathrm{S}$ & $\mathrm{S}$ & W & $\mathrm{S}$ & $\mathrm{S}$ & $\mathrm{S}$ & $\mathrm{W}$ & $\mathrm{S}$ & $\mathrm{S}$ & $\mathrm{S}$ & $\mathrm{S}$ & $\mathrm{M}$ & $\mathrm{S}$ & $\mathrm{S}$ & $\mathrm{S}$ & $\mathrm{S}$ & & & & \\
\hline Ulex europaeus & $\mathrm{S}$ & $\mathrm{S}$ & $\mathrm{M}$ & $\mathrm{S}$ & $\mathrm{S}$ & $\mathrm{S}$ & $\mathrm{S}$ & $\mathrm{M}$ & $\mathrm{S}$ & $\mathrm{S}$ & $\mathrm{S}$ & $\mathrm{M}$ & $\mathrm{S}$ & $\mathrm{S}$ & $\mathrm{S}$ & $\mathrm{S}$ & $\mathrm{S}$ & $\mathrm{S}$ & $\mathrm{S}$ & $\mathrm{S}$ & $\mathrm{S}$ & $\mathrm{S}$ & M & $\mathrm{M}$ \\
\hline \multicolumn{25}{|l|}{$\mathbf{N}$} \\
\hline Arachis hypogaea & $\mathrm{M}$ & $\mathrm{S}$ & $\mathrm{S}$ & $\mathrm{S}$ & $\mathrm{S}$ & $\mathrm{S}$ & $\mathrm{S}$ & $\mathrm{S}$ & $\mathrm{S}$ & $\mathrm{S}$ & $\mathrm{S}$ & $\mathrm{S}$ & & & & & & & & & & & & \\
\hline Canavalia ensiformis & $\mathrm{M}$ & $\mathrm{S}$ & $\mathrm{S}$ & $\mathrm{W}$ & $\mathrm{S}$ & $\mathrm{S}$ & $\mathrm{S}$ & W & $\mathrm{S}$ & $\mathrm{S}$ & $\mathrm{S}$ & W & $\mathrm{S}$ & $\mathrm{S}$ & $\mathrm{S}$ & $\mathrm{W}$ & & & & & & & & \\
\hline Glycine max & $\mathrm{M}$ & $\mathrm{S}$ & $\mathrm{S}$ & $\mathrm{M}$ & $\mathrm{S}$ & $\mathrm{S}$ & $\mathrm{S}$ & W & $\mathrm{S}$ & $\mathrm{S}$ & $\mathrm{S}$ & W & $\mathrm{S}$ & $\mathrm{S}$ & $\mathrm{S}$ & $\mathrm{W}$ & $\mathrm{S}$ & $\mathrm{S}$ & $\mathrm{S}$ & $\mathrm{S}$ & & & & \\
\hline Ulex europaeus & $\mathrm{M}$ & M & $\mathrm{S}$ & $\mathrm{S}$ & $\mathrm{S}$ & $\mathrm{S}$ & $\mathrm{S}$ & $\mathrm{S}$ & $\mathrm{S}$ & $\mathrm{S}$ & $\mathrm{S}$ & $\mathrm{S}$ & $\mathrm{S}$ & $\mathrm{S}$ & $\mathrm{S}$ & $\mathrm{S}$ & $\mathrm{S}$ & $\mathrm{S}$ & $\mathrm{S}$ & W & $\mathrm{S}$ & $\mathrm{S}$ & $\mathrm{S}$ & W \\
\hline \multicolumn{25}{|l|}{$\mathbf{P}$} \\
\hline Arachis hypogaea & $\mathrm{S}$ & $\mathrm{M}$ & $\mathrm{W}$ & W & $\mathrm{S}$ & $\mathrm{S}$ & W & $\mathrm{M}$ & $\mathrm{S}$ & $\mathrm{S}$ & W & $\mathrm{M}$ & & & & & & & & & & & & \\
\hline Canavalia ensiformis & $\mathrm{M}$ & $\mathrm{M}$ & $\mathrm{M}$ & W & $\mathrm{S}$ & $\mathrm{S}$ & W & W & $\mathrm{S}$ & $\mathrm{S}$ & W & W & $\mathrm{S}$ & $\mathrm{S}$ & $\mathrm{S}$ & $\mathrm{S}$ & & & & & & & & \\
\hline Glycine max & $\mathrm{M}$ & W & $\mathrm{W}$ & $\mathrm{S}$ & $\mathrm{S}$ & $\mathrm{S}$ & W & $\mathrm{S}$ & $\mathrm{S}$ & $\mathrm{S}$ & W & $\mathrm{S}$ & $\mathrm{S}$ & $\mathrm{S}$ & $\mathrm{S}$ & $\mathrm{S}$ & $\mathrm{S}$ & $\mathrm{S}$ & $\mathrm{S}$ & $\mathrm{M}$ & & & & \\
\hline Ulex europaeus & $\mathrm{S}$ & M & W & $\mathrm{M}$ & $\mathrm{S}$ & $\mathrm{S}$ & W & W & $\mathrm{S}$ & $\mathrm{S}$ & W & $\mathrm{W}$ & $\mathrm{S}$ & $\mathrm{S}$ & $\mathrm{S}$ & $\mathrm{S}$ & $\mathrm{S}$ & $\mathrm{S}$ & $\mathrm{S}$ & $\mathrm{S}$ & $\mathrm{S}$ & $\mathrm{S}$ & $\mathrm{S}$ & $\mathrm{S}$ \\
\hline \multicolumn{25}{|l|}{ CNP } \\
\hline Arachis hypogaea & $\mathrm{S}$ & $\mathrm{S}$ & $\mathrm{M}$ & $\mathrm{S}$ & $\mathrm{S}$ & $\mathrm{M}$ & W & W & $\mathrm{S}$ & $\mathrm{M}$ & W & W & & & & & & & & & & & & \\
\hline Canavalia ensiformis & $\mathrm{S}$ & $\mathrm{S}$ & $\mathrm{S}$ & $\mathrm{S}$ & $\mathrm{S}$ & $\mathrm{M}$ & $\mathrm{M}$ & W & $\mathrm{S}$ & $\mathrm{M}$ & $\mathrm{M}$ & W & $\mathrm{S}$ & $\mathrm{S}$ & $\mathrm{S}$ & $\mathrm{S}$ & & & & & & & & \\
\hline Glycine max & $\mathrm{M}$ & $\mathrm{S}$ & W & $\mathrm{S}$ & $\mathrm{S}$ & $\mathrm{M}$ & W & W & $\mathrm{S}$ & $\mathrm{M}$ & W & W & $\mathrm{S}$ & M & $\mathrm{M}$ & $\mathrm{S}$ & $\mathrm{S}$ & $\mathrm{S}$ & M & $\mathrm{S}$ & & & & \\
\hline Ulex europaeus & $\mathrm{S}$ & $\mathrm{S}$ & $\mathrm{M}$ & $\mathrm{S}$ & $\mathrm{M}$ & $\mathrm{M}$ & W & W & $\mathrm{M}$ & M & W & $\mathrm{W}$ & $\mathrm{S}$ & $\mathrm{S}$ & $\mathrm{M}$ & $\mathrm{S}$ & $\mathrm{S}$ & $\mathrm{S}$ & M & $\mathrm{S}$ & $\mathrm{S}$ & M & W & $\mathrm{S}$ \\
\hline
\end{tabular}

Ulex europaeus binding was also sensitive to changes in biofilm glycoconjugate composition, showing significant changes in Weeks, 1, 3 and 5 (Table 5). These results indicated that the method was sensitive to changes in glycoconjugate chemistry with time in the biofilm. Such changes in EPS chemistry may be related to observable changes in the sorption of contaminants (Wolfaardt et al. 1998, Lawrence et al. 2001) and palatability (Lawrence et al. 2002) for invertebrates; however, these relationships remain to be established.

\section{Effects of nutrients on EPS production}

We found that the highest total glycoconjugate production was associated with nutrient additions, but was only significantly increased by the combined CNP applications (Fig. 2). Polysaccharide production has been reported to be highest when excess carbohydrate in the media was available while other nutrients such as N, P or S were limited (Sutherland 1977, 1982). This has been shown for batch and continuous

Table 5. Results of analysis of variance in lectin-binding data (biovolume) as a function of time (wk). Analyses examined each treatment within each lectin type and time interval. Values with same letter are not significantly different at $\mathrm{p} \leq 0.05$

\begin{tabular}{|c|c|c|c|c|c|c|c|c|c|}
\hline \multirow{2}{*}{ Treatment } & \multicolumn{4}{|c|}{ Time (wk) } & \multirow{2}{*}{ Treatment } & \multicolumn{4}{|c|}{ Time (wk) } \\
\hline & 1 & 3 & 5 & 7 & & 1 & 3 & 5 & 7 \\
\hline \multicolumn{5}{|c|}{ Arachis hypogaea } & \multicolumn{5}{|l|}{ Glycine max } \\
\hline Control & $0.07 \mathrm{a}$ & $0.48 a$ & $0.25 a$ & $0.91 \mathrm{a}$ & Control & $0.04 \mathrm{a}$ & $0.72 \mathrm{ab}$ & $0.51 \mathrm{ab}$ & $0.70 \mathrm{a}$ \\
\hline $\mathrm{C}$ added & $0.09 a$ & $0.72 b$ & $0.49 \mathrm{a}$ & $0.69 a$ & $\mathrm{C}$ added & $0.06 a$ & $0.45 \mathrm{a}$ & $0.45 b$ & $0.53 \mathrm{a}$ \\
\hline $\mathrm{N}$ added & $0.12 \mathrm{a}$ & $0.42 \mathrm{a}$ & $0.50 \mathrm{a}$ & $0.46 a$ & $\mathrm{~N}$ added & $0.05 a$ & $0.65 \mathrm{ab}$ & $0.28 \mathrm{ab}$ & $0.54 \mathrm{a}$ \\
\hline $\mathrm{P}$ added & $0.20 \mathrm{a}$ & $0.78 \mathrm{~b}$ & $0.50 \mathrm{a}$ & $0.68 \mathrm{a}$ & $\mathrm{P}$ added & $0.07 \mathrm{a}$ & $0.83 b$ & $0.21 \mathrm{a}$ & $0.62 \mathrm{a}$ \\
\hline CNP added & $0.76 \mathrm{~b}$ & $0.48 \mathrm{a}$ & $0.37 \mathrm{a}$ & $0.67 \mathrm{a}$ & CNP added & $0.47 \mathrm{a}$ & $0.49 \mathrm{a}$ & $0.30 \mathrm{ab}$ & $0.56 \mathrm{a}$ \\
\hline \multicolumn{5}{|c|}{ Canavalia ensiformis } & \multicolumn{5}{|l|}{ Ulex europaeus } \\
\hline Control & $0.05 \mathrm{a}$ & $0.63 a$ & $1.4 \mathrm{c}$ & $0.22 \mathrm{~b}$ & Control & $0.02 \mathrm{a}$ & $0.15 a$ & $0.02 \mathrm{a}$ & $0.26 \mathrm{ab}$ \\
\hline $\mathrm{C}$ added & $0.13 \mathrm{abc}$ & $0.63 a$ & $0.34 \mathrm{a}$ & $0.28 \mathrm{bc}$ & $\mathrm{C}$ added & $0.09 \mathrm{bc}$ & $0.18 a b$ & $0.15 b$ & $0.26 \mathrm{ab}$ \\
\hline $\mathrm{N}$ added & $0.10 \mathrm{ab}$ & $0.91 \mathrm{a}$ & $0.52 \mathrm{ab}$ & $0.25 \mathrm{~b}$ & $\mathrm{~N}$ added & $0.06 \mathrm{~b}$ & $0.21 \mathrm{ab}$ & $0.11 \mathrm{ab}$ & $0.07 \mathrm{a}$ \\
\hline $\mathrm{P}$ added & $0.17 b$ & $0.70 \mathrm{a}$ & $0.44 \mathrm{a}$ & $0.38 \mathrm{c}$ & $\mathrm{P}$ added & $0.14 \mathrm{C}$ & $0.30 \mathrm{~b}$ & $0.07 \mathrm{ab}$ & $0.07 \mathrm{a}$ \\
\hline CNP added & $0.20 \mathrm{bc}$ & $0.54 \mathrm{a}$ & $0.87 b$ & $0.09 \mathrm{a}$ & CNP added & $0.14 \mathrm{c}$ & $0.17 \mathrm{a}$ & $0.09 \mathrm{ab}$ & $0.46 \mathrm{~b}$ \\
\hline
\end{tabular}


cultures of Pseudomonas sp. (Williams \& Wimpenny 1977, 1978). Some studies have reported that, under nutrient limitation, the ratio of nutrients to available organic carbon can increase overall EPS production. This was the case for Zooglea sp. in pure culture (Norberg \& Enfors 1982). Mohamed et al. (1998), in a qualitative examination of Fraser River biofilms, found that there appeared to be less extensive glycoconjugates in treatments containing phosphorus; they attributed this in part to increased grazing pressure in the presence of phosphorus additions. Wetzel et al. (1997) reported that when they added DOC in the form of leachates from aquatic macrophytes, there was a 10 to $57 \%$ reduction in EPS in biofilm communities. They speculated that this was a reflection of the reduced requirement for EPS as a mechanism for nutrient retention. In the South Saskatchewan River, water which is carbon- and nutrient-limited, only the application of CNP combined was able to increase total EPS glycoconjugates in the biofilm. Freeman \& Lock (1995) demonstrated that EPS of river biofilms had an extensive capacity for retention of carbon resources that could be accessed by bacteria during periods of low available carbon. This phenomenon was also observed in studies of a degradative biofilm community by Wolfaardt et al. (1994). Given the ecological significance of EPS as a carbon source for other trophic levels (Decho 1990, Decho \& Moriarty 1990) this indicates the importance of not only the total nutrient availability in the system, but also the ratio of $\mathrm{C}: \mathrm{N}: \mathrm{P}$ in determining its availability.

\section{Effect of nutrient ratio on EPS composition}

The observed similarity of the biofilm response in the single nutrient $\mathrm{C}, \mathrm{N}$, and $\mathrm{P}$ treatments and the similarity between the control and CNP treatments (Figs. 3, 4 \& 6) was probably a result of carbon and nutrient limitation in the single nutrient applications resulting in unbalanced nutrition relative to the unamended and combined nutrient treatments. The combined amendment was designed to produce in the range of $10^{8}$ cells ml ${ }^{-1}$ with carbon, nitrogen and phosphorus all available (Mohamed et al. 1998). This would be a balanced nutrient addition, while single nutrient additions could create limitations in carbon or other nutrients. These observations may be due to changes in the nature of the glycoconjugates produced by individual organisms or changes in the species make-up of the biofilm communities. Examination of the bacterial, algal and total EPS composition of the biofilm communities at Week 7 (Fig. 2) reveals broad similarity in the single nutrient treatments, which are more EPS-dominated, than the control, which displays a significant $(p=0.05)$ dominance of bacterial biomass, and the CNP which is dominated by photosynthetic biomass. This indicates that gross changes in community composition do not fully account for the similarities and differences observed in these systems. The glycoconjugate analyses in Fig. 4 (the proportional representation of the glycoconjugate binding with time and treatment) show that during Weeks 1,3 and 5, the pattern of similarity between the single nutrient treatments and the similarity between the control and combined treatment are consistent. The deviation at Week 7 may be attributable to sloughing events and regrowth.

A variety of studies have shown that the type and amount of EPS produced by microorganisms are influenced by various environmental conditions. Lee et al. (1997) found that medium $\mathrm{pH}$ influenced the types and amounts of EPS, while growth medium composition also clearly affects EPS type and quantity (Tavernier et al. 1997). Carbon source also dramatically influenced the glycoconjugate make-up of a degradative biofilm community, as revealed by lectin staining and in situ analyses (Wolfaardt et al. 1998). These shifts could be attributable to changes in the relative abundance of community members under the influence of their carbon source. Michael \& Smith (1995) used Canavalia ensiformis, Limulus polyphemus and Helix pomatia lectins to probe 1 and $3 \mathrm{~d}$ old biofilms, and found differences in binding patterns as a function of age and whether the biofilm was on glass or on seagrass. Böckelmann et al. (2002) also showed that the glycoconjugate composition of aggregates in the Elbe river appeared to differ from that observed in the South Saskatchewan River in parallel studies. Elbe river aggregates exhibited a high degree of Triticum vulgaris lectin binding, while those of the South Saskatchewan River were characterised by binding of lectin obtained from Glycine max. Changes in sugar inhibition patterns from year to year have also been used to detect changes in biofilm glycoconjugate composition (Neu et al. 2001): in one year, application of mannose inhibited binding of Arachis hypogaea and Ulex europaeus lectins, whereas in a subsequent year mannose resulted in a substantial enhancement of binding by these same lectins. Thus, seasonal, year to year and spatial variations occur in natural biofilm and aggregate communities. These changes may result in substantial variation in sorption parameters influencing the chemo-dynamics of a variety of contaminants. For example, Lawrence et al. (2001) demonstrated that a unique microcolony type unexpectedly bound the hydrophilic herbicide atrazine and metabolites in its glycoconjugate matrix. 


\section{Role of microbial community composition (FISH)}

As noted above, the changes detected in the glycoconjugates may be associated with changes in community structure in response to nutrient additions. The studies of Manz et al. (1999) and Böckelmann et al. (2000) have confirmed the high diversity of bacteria present in riverine habitats, while other studies have confirmed the presence of a wide range of glycoconjugates in biofilms and aggregates in these habitats (Neu 2000, Neu et al. 2001). Böckelmann et al. (2002) further demonstrated the association of glycoconjugates with bacteria through combined FISH and lectin analyses. Using a suite of rRNA probes and FISH, Manz et al. (1999) demonstrated that the South Saskatchewan River biofilm community changed during the developmental period. They found that beta-proteobacteria constituted the morphologically most diverse group within the biofilm communities, and were often the dominant or second-most dominant community members. We therefore applied the Beta42a probe to Week 2 and Week 5 biofilms from each treatment ( 3 reactors, 1 slide per reactor with 20 fields of view) to assess the influence of nutrient treatments on this population (Fig. 7). The results indicated significant variation in this population in response to nutrient addition. At $5 \mathrm{wk}$, the probe results indicated that control, $\mathrm{C}$, and $\mathrm{N}$ treatments were not significantly

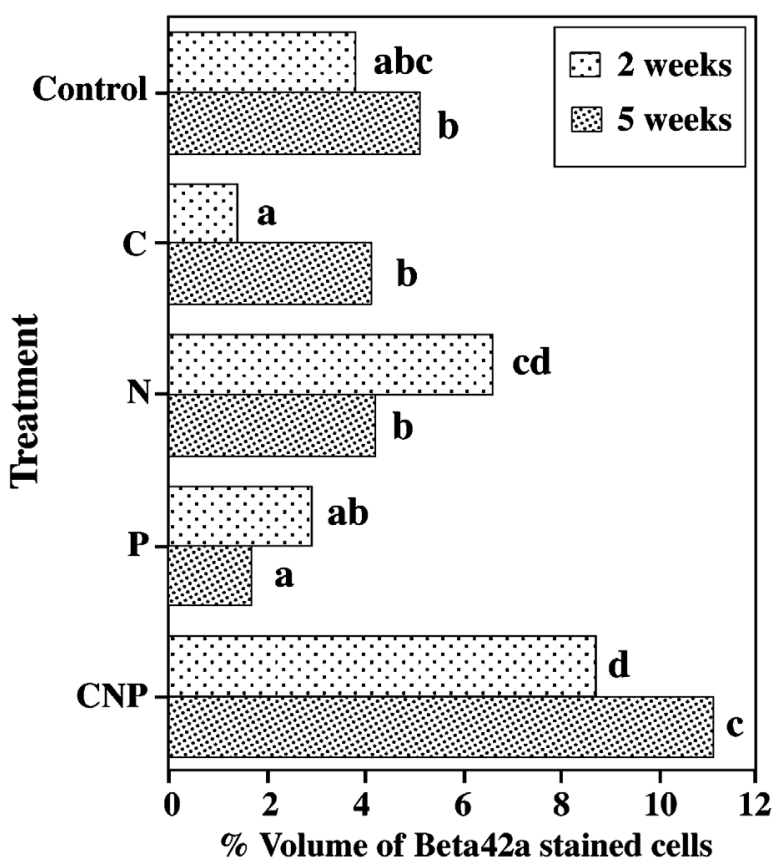

Fig. 7. Results of image analyses of river biofilms hybridised with rRNA probe Beta42a specific for beta-proteobacteria. Bars followed by different letters are significantly different at $\mathrm{p} \leq 0.05$ different, whereas $\mathrm{P}$ application resulted in a significant decrease and CNP in a significant increase in Beta42a signal. These results indicate significant community changes resulting from nutrient treatment, and also parallel trends observed for binding of Canavalia ensiformis at $5 \mathrm{wk}$, for which significant $\mathrm{p} \leq 0.05$ differences were also detected in P and CNP treatments (Table 5).

\section{CONCLUSIONS}

In situ analysis using CLSM and a panel of glycoconjugate-specific probes in combination with digital image analysis provided an effective method for comparison of treatment effects on the lectin-specific EPS components of river biofilms. Lectin-binding analysis allowed the assessment and quantification of changes in the glycoconjugates of biofilms as a result of nutrient amendment. Further, these studies confirm the diversity of glycoconjugates present in river biofilms and their response to nutrients. However, the role of individual microorganisms or groups in the development of the glycoconjugate structure of river biofilms remains poorly understood. The results suggest that the relationship between bacteria and algae as influenced by nutrients plays an important role in determining glycoconjugate structure. Further investigation of this area is important because of its relationship to the environmental fate and effects of various contaminants in river biofilm communities.

Acknowledgements. This study was supported by the Toxic Substances Research Initiative of Health Canada, the Canadian-German Agreement on scientific and research cooperation (grants ENV 46/2, KAN 034/98 ENV), the National Water Research Institute, Environment Canada and the UFZ Centre for Environmental Research, Magdeburg, Germany.

\section{LITERATURE CITED}

Böckelmann U, Manz W, Neu TR, Szewzyk U (2000) Characterization of the microbial community of lotic organic aggregates ('river snow') in the Elbe river of Germany by cultivation and molecular techniques. FEMS Microbiol Ecol 33:157-170

Böckelmann U, Manz W, Neu TR, Szewzyk U (2002) A new combined technique of fluorescent in situ hybridization and lectin-binding-analysis (FISH-LBA) for the investigation of lotic microbial aggregates. J Microbiol Methods 49: 75-87

Bonet R, Simon-Pujol MP, Congregado F (1993) Effects of nutrients on exopolysaccharide production and surface properties of Aeromonas salmonicida. Appl Environ Microbiol 59:2437-2441

Decho A (1990) Microbial exopolymer secretions in ocean environments: their role(s) in food webs and marine processes. Oceanogr Mar Biol Annu Rev 28:73-153 
Decho AW, Moriarty DJW (1990) Bacterial exopolymer utilization by a harpacticoid copepod: a methology and results. Limnol Oceanogr 35:1039-1049

Environment Canada (1992) Analytical methods manuals. Inland Waters Directorate, Water Quality Branch, Environment Canada, Ottawa, ON

Flemming HC, Schmitt J, Marshall KC (1996) Sorption properties of biofilms. In: Calmano W, Förstner U (eds) Sediment and toxic substances. Springer-Verlag, Berlin, p 115-157

Freeman C, Lock MA (1995) The biofilm polysaccharide matrix: a buffer against changing substrate supply. Limnol Oceanogr 40:273-278

Geesey GG, Jang L, Jolley JG, Hankins MR, Iwaoka T, Griffiths PR (1989) Binding of metal ions by extracellular polymers of biofilm bacteria. In: Jenkins D, Olson BH (eds) Water and wastewater microbiology. Pergamon Press, Oxford, p 161-165

Jickells TD (1998) Nutrient biogeochemistry of the coastal zone. Science 281:217-222

Lawrence JR, Neu TR, Swerhone GDW (1998) Application of multiple parameter imaging for the quantification of algal, bacterial and exopolymer components of microbial biofilms. J Microbiol Methods 32:253-261

Lawrence JR, Swerhone GDW, Neu TR (2000) A simple rotating annular reactor for replicated biofilm studies. J Microbiol Methods 42:215-224

Lawrence JR, Kopf G, Headley JV, Neu TR (2001) Sorption and metabolism of selected herbicides in river biofilm communities. Can J Microbiol 47:634-641

Lawrence JR, Scharf B, Packroff G, Neu TR (2002) Microscale evaluation of the effects of grazing by invertebrates with contrasting feeding modes on river biofilm architecture and composition. Microb Ecol 43:199-207

Lee IY, Seo WT, Kim GJ, Kim MK, Ahn SG, Kwon GS, Park YH (1997) Optimization of fermentation conditions for production of exopolysaccharide by Bacillus polymyxa. Bioprocess Eng 16:71-75

Manz W, Wendt-Potthoff K, Neu TR, Szewzyk U, Lawrence JR (1999) Phylogenetic composition, spatial structure, and dynamics of lotic bacterial biofilms investigated by fluorescent in situ hybridization and confocal laser scanning microscopy. Microb Ecol 37:225-237

Michael T, Smith CM (1995) Lectins probe molecular films in biofouling: characterization of early films on non-living and living surfaces. Mar Ecol Prog Ser 119:229-236

Mohamed MN, Lawrence JR, Robarts RD (1998) Phosphorus limitation of heterotrophic biofilms from the Fraser River, British Columbia, and the effect of pulp mill effluent. Microb Ecol 36:121-130

Neu TR (2000) In situ cell and glycoconjugate distribution in river snow studied by confocal laser scanning microscopy. Aquat Microb Ecol 21:85-95

Neu TR, Lawrence JR (1997) Development and structure of microbial biofilms in river water studied by confocal laser scanning microscopy. FEMS Microbiol Ecol 24:11-25

Neu TR, Lawrence JR (1999a) In situ characterization of extracellular polymeric substances (EPS) in biofilm systems. In: Wingender J, Neu TR, Flemming HC (eds) Microbial extracellular polymeric substances. Springer-Verlag, Heidelberg, p 21-47

Editorial responsibility: Bess Ward,

Princeton, New Jersey, USA
Neu TR, Lawrence JR (1999b) Lectin-binding-analysis in biofilm systems. Methods Enzymol 310:145-152

Neu TR, Swerhone GDW, Lawrence JR (2001) Assessment of lectin-binding analysis for in situ detection of glycoconjugates in biofilm systems. Microbiology (UK) 147: 299-313

Nielsen PH, Jahn A (1999) Extraction of EPS. In: Wingender J, Neu TR, Flemming HC (eds) Microbial extracellular polymeric substances. Springer-Verlag, Heidelberg, p 49-72

Norberg A, Enfors S (1982) Production of extracellular polysaccharide by Zooglea ramigera. Appl Environ Microbiol 44:1231-1237

Sabra W, Zeng AP, Deckwer WD (2001) Bacterial alginate: physiology product quality and process aspects. Appl Microbiol Biotechnol 56:315-325

Staudt C, Horn H, Hempel DC, Neu TR (2003) Screening of lectins for staining lectin-specific glycoconjugates in the EPS of biofilms. In: Lens P, Moran AP, Mahony T, Stoodley $\mathrm{P}, \mathrm{O}^{\prime}$ Flaherty V (eds) Biofilms in medicine, industry and environmental technology. International Water Association (IWA) Publishing, London, p 308-327

Sutherland IW (1977) Bacterial exopolysaccharides their nature and production. In: Sutherland IW (ed) Surface carbohydrates of the procaryotic cell. Academic Press, New York, p 27-96

Sutherland IW (1982) Biosynthesis of microbial exopolysaccharides. Adv Microb Physiol 23:79-150

Tavernier P, Portais J, Nava Saucedo JE, Courtois J, Courtois B, Barbotin J (1997) Exopolysaccharide and poly-(beta)hydroxybutyrate coproduction in two Rhizobium meliloti strains. Appl Environ Microbiol 63:21-26

Uhlinger DJ, White DC (1983) Relationship between physiological status and formation of extracellular polysaccharide glycocalyx in Pseudomonas atlantica. Appl Environ Microbiol 45:64-70

Wetzel RG, Ward AK, Stock M (1997) Effects of natural dissolved organic matter on mucilaginous matrices of biofilm communities. Arch Hydrobiol 139:289-299

Williams AG, Wimpenny JWT (1977) Exopolysaccharide production by Pseudomonas NCIB11264 grown in batch culture. J Gen Microbiol 102:13-21

Williams AG, Wimpenny JWT (1978) Exopolysaccharide production by Pseudomonas NCIB11264 grown in continuous culture. J Gen Microbiol 104:47-57

Wingender J, Flemming HC, Neu TR (1999) What are bacterial extracellular polymeric substances. In: Wingender J, Neu TR, Flemming HC (eds) Microbial extracellular polymeric substances. Springer-Verlag, Heidelberg, p 1-19

Wolfaardt GM, Lawrence JR, Robarts RD, Caldwell DE (1994) Bioaccumulation of the herbicide Diclofop in extracellular polymers and its utilization by a biofilm community during starvation. Appl Environ Microbiol 61:152-158

Wolfaardt GM, Lawrence JR, Robarts RD, Caldwell DE (1998) In situ characterization of biofilm exopolymers involved in the accumulation of chlorinated organics. Microb Ecol 35: 213-223

Wolfaardt GM, Lawrence JR, Korber DR (1999) Function of EPS in microbial biofilms. In: Wingender J, Neu TR, Flemming HC (eds) Microbial extracellular polymeric substances. Springer-Verlag, Heidelberg, p 171-200

Submitted: August 4, 2003; Accepted: October 22, 2004

Proofs received from author(s): February 21, 2005 